UDC 612. 015. 11: 612. 612. 014 .6]; (612. 112.94+611-018.74)

\title{
Nitric oxide as the main multifunctional regulator of immunocompetent and endothelial cells
}

\author{
O. V. Sadlyak, M. A. Kolishetska, M. L. Baida, Kh. G. Musij-Sementsiv, \\ N. G. Sementsiv, R. B. Lesyk \\ Danylo Halytsky Lviv National Medical University \\ 69, Pekarska Str., Lviv, Ukraine, 79010 \\ nsen@online.ua
}

\begin{abstract}
Nitric oxide (NO) plays an important role in metabolism. Consequently, every tissue of our body is affected by changes in concentrations of nitric oxide and its metabolites. Here we analyze phenotypic effects of NO and its metabolites in macrophages, NK-cells and lymphocytes that perform protection of the host organism against malignant tumors and intracellular pathogens. Immune system imbalance may result from misregulation of NO synthesis. Nitric oxide also plays an important role in endothelial dysfunction including inhibition of platelet adhesion and aggregation, vasoconstriction and vasodilation disorders of blood vessels, blood rheology changes and the development of atherosclerotic plaques. Thus an imbalance in the synthesis of nitric oxide in the vascular endothelium may be an early marker of lesions of various origins.
\end{abstract}

Ke y w or d s: NO-synthases, lymphocytes, immune system, inflammation, endothelial dysfunction, endotheliocytes.

\section{Introduction}

Nitric oxide [(NO)], easily penetrating through biological membranes, is a natural unique secondary messenger, since it not only takes part in implementation of physiological processes, but causes many pathological states in a living organism. The NO effect on cells depends on its amount, which in turn depends on different NO-synthases isoforms (NOS), but, as a rule, this effect is primarily caused by inducible NO-synthases (iNOS) [1-3]. The key function of NO produced by iNOS is involving in the immune processes, including antipathogenic reactions, non-specific cytotoxicity, antitumor protection, transplantant rejection reactions etc.

Nitric oxide and immune system. Nitric oxide has been recently determined as one of the most diverse factors that exhibit their regulative effect on the immune system affecting inter- and intracellular molecules and mediating the immune response [4-6]. NO is involved in pathogenesis and control of infectious, tumor, autoimmune processes and chro-

(C) 2017 O. V. Sadlyak et al.; Published by the Institute of Molecular Biology and Genetics, NAS of Ukraine on behalf of Biopolymers and Cell. This is an Open Access article distributed under the terms of the Creative Commons Attribution License (http://creativecommons.org/licenses/by/4.0/), which permits unrestricted reuse, distribution, and reproduction in any medium, provided the original work is properly cited 
nic degenerative diseases [7-9]. However, nowadays there is no simple and clear picture of the NO effect on the immune system. The protective and toxic $\mathrm{NO}$ effects can often be observed simultaneously [10, 11]. Being produced by the range of cells involved in immune and inflammatory reactions (macrophages, dendritic cells, lymphocytes, neutrophils, eosinophils, monocytes, Kupffer cells, hepatocytes, microglia, endothelial, epithelial cells, fibroblasts etc.), NO plays an important role affecting the processes of their maturation, differentiation, proliferation and apoptosis [12-15]. According to the literature data [5, 16-20], NO produces an active effect on:

- selection and maturation of T-lymphocytes in the thymus;

- lymphocyte migration and recirculation and balance of the population-clonal composition;

- maintaince of the T-helper-suppressor balance;

- thymus age involution;

- IFN $\gamma$ production by NK-cells and support of their cytolytic properties;

- decrease/increase of cytokines synthesis resulting in stimulation/inhibition of cytotoxic function of immunocompetent cells] [21, 22].

Nowadays the question of synthesis of NOS isoforms by primary $\mathrm{T}$ - and $\mathrm{B}-\mathrm{lym} p h o c y t e s$ is still open [23-25]. At the early stage of immune response, NO induces the series of important effector functions of immune cells [26]. In the first four hours after thepathogenic agent entrusion into the organism, the nonspecific mechanisms of innate immunity are activated; neutrophils, macrophages, NK-cells and the complement system take part in the implementation mechanisms. The phagocytes, which are acti- vated by the pathogens, produce proinflammatory cytokines (TNF $\alpha$, IL-12 etc.), which induce thesynthesis of IFN $\gamma$ by stimulated NK-cells. $\mathrm{TNF} \alpha$ and IFN $\gamma$ are promoters of the iNOS in immunocompetent cells - the NO, which is produced by them, mediates killing microbial pathogens, but excessive concentration of the radicals in NK-cells impairs their function [2732]. A capacity of T-cells of switching the IFN $\gamma$ program from proliferation to apoptosis under the influence of $\mathrm{NO}$ has been proved. Additionally, NO is able to induce interferonindependent apoptosis of T-cells by affecting their proliferation directly [11,33-36].

The lymphocyte migration and recirculation processes, antibody production, proliferation of $\mathrm{T}$ - and B-lymphocytes, production of cytokines and a number of proteins and enzymes, formation of different cell adhesion molecules, such as VCAM-1, ICAM-1, E-selectin (CD62E) and $\mathrm{P}$-selectin (CD62R), are inhibited as a consequence of significant increase of NO level [37-45].

The progression of an allergic type of inflammation is related to the effect of elevated concentrations of $\mathrm{NO}$ and its derivatives on eosinophils due to suppression of Fas-dependent apoptosis. At the same time, the induction of NO-dependent neutrophilic apoptosis contributes to the inhibition of allergic inflammation. Cytostatic-cytotoxic effects of nitric oxide and peroxynitrite, caused by NO action in the process of «respiratory explosion» in macrophages, contribute to more active elimination of infectious agents [43-45].

Some authors $[17,29]$ describe the NO impact on the change in the helper T-lymphocytes subpopulations pattern that causes modification of cytokines set produced by Th1 and Th 2 types of cells, and as a consequence - the qualitative and quantitative imbalance in the immune sys- 
tem $[34,46]$. Under these circumstances, the regulatory function of T-lymphocytes is impaired resulting in "slipping out" the transformed cells immunologic control and possible tumor development [47-49]. The NK-lymphocytes use $\mathrm{NO}$ or its derivatives for elimination of bacteria and transformed cells. However, an excess of NOS inducible isoform and NO metabolism products, causing the immunity disbalance, reduces the NK cytotoxic capacity by stimulating premature apoptosis and even necrosis [50-53].

In cases of immune and inflammatory processes, the iNOS expression clearly correlates with the disease progression that can point to its ototoxic and / or immunosuppressive effect [54-57].

The NO role in the autoimmune diseases development is being actively studied. The nitration of proteins caused by NO increases their antigenicity resulting in a severe course of autoimmune processes and manifestations of autoimmune disease [58, 59]. Thus, experimental autoimmune disease [60] was accompanied by a significant increase in the NO production with an increased level of $\mathrm{NO}_{2}^{-}$/ $\mathrm{NO}_{3}{ }^{-}$in blood. Difficult course of sclerodermia was accompanied by a change in the NO synthesis [61]. The NO effect is also important in the rheumatoid arthritis pathogenesis [62]. The iNOS activation, mediated by cytokines and TNF $\alpha$, causes a cytotoxic effect in the cells of synovial fluid of joints [63, 64]. According to [65], the level of nitrites / nitrates in patients with rheumatoid arthritis increased regardless of gender and correlates directly with the stage of disease. The iNOS activity increased upon multiple sclerosis causing not only a cytotoxic effect but also a damage of blood-brain barrier and its higher permeability [8]. High concentration of $\mathrm{NO}$ and products of its me- tabolism is also determined in blood and cerebrospinal fluid of patients with systemic lupus erythematosus (SLE) - synthesis of NO is being increased with the disease progression $[58,66]$. Additionally, inhibition of proliferation and increased apoptosis of lymphocytes and macrophages cause the development of secondary immunodeficiency [67].

Along with a cytotoxic effect of NO, there are many examples of its cytoprotective effect, particularly, in the B-lymphocytes and human cell cultures in vitro, such as splenocytes, eosinophils, hepatocytes, endothelial cells [68]. The NO protective effect in different cell types is mediated by cAMP [6]. Probably, cAMP synthesized under the NO effect can activate cAMP-dependent protein kinases, which, in turn, affect apoptotic proteins (e.g., caspases, Vs1-2). Antiapoptotic effect of NO associated with inhibition of caspases is of interest as well. Active forms of NO influence cysteine, a residue in the caspase active center, by nitration of SH groups, causing inhibition of caspase cascade. Some authors $[53,69]$ emphasize the enhanced expression of heat shock proteins (Hsp) that protect cells against various stresses; the NO antiapoptotic effect correlates with an increase of Hsp synthesis.

Currently there is almost no data on the role of NO metabolism arginase pathway in immunocompetent cells [25]. The fact is that arginase starts to work in activated macrophages and lymphocytes in parallel with NO-synthase. Under such conditions, arginase can compete with NO-synthase for the common substrate arginine and even inhibit the formation of NO. Excessive arginase synthesis $[5,25,70]$ in the organism correlates with pathology, moreover, with the tendency to develop chronic processes 
[71]. Enhanced arginase production results in the imbalance in biosyntesis of polyamines and plays an important role in the proliferation of all mammalian cells. Polyamines noncovalently interact with various biomacromolecules, being a part of chromatin involved in replication of DNA, and their concentration significantly increases in the periods of active cell division and tissue growth $[40,72]$. Disturbed metabolism of polyamines may be a serious factor of carcinogenesis. The arginase activity is increased in tumor cells, and, therefore, can be used as a marker in early diagnosis of tumors. A reduction of polyamines synthesis causes inhibition of the tumor cells metastasis in vitro and in vivo [25].

Consequently, it can be assumed that imbalance of two pathways - oxidative (NOsynthase) and not oxidative (arginase) - leads to serious changes in immunocompetent cells and immune reactions.

L-arginine nitric oxide system and endothelium. A number of recent studies have obviously changed the opinion concerning the vascular endothelium and its role in the overall homeostasis [73-76]. It was revealed that endothelium synthesizes a large amount of biologically active substances that play an important role in various processes of living organism, in norm and pathology. These substances are mostly paracrine (in neighboring cells) or autocrine-paracrine (in endothelium) $[2,77]$. However, a vascular wall is a dynamic structure, its endothelium is constantly being renewed, dead fragments containing biologically active substances enter blood, spread throughout the organism and may affect systemic circulation [78-80].

Endothelium regulates hemodynamic reactions, hemostasis, immune reactions, regenera- tion etc.; it is considered to be one of the diffuse endocrine systems [81]. Endothelial cells synthesize several regulatory hormonal substances called histohormons. The location on the border between tissues and blood underlies a special structure of endothelium. The intimal layer of the vessel wall is extremely smooth and covered with a mucous membrane - glycocalyx. Glycocalyx is composed of mucopolysaccharides possessing antiadhesive properties: they protect blood cells against adhesion to the blood vessel walls. There are a large number of specific receptors on the glycocalyx surface. It supports the binding of thrombin and prevents the adhesion of platelets to the endothelium [82].

The L-arginine-nitric-oxide system is a main biochemical unit to implement all physiological functions of endothelium in the organism [25]. $\mathrm{NO}$ is contained in all endothelial cells regardless of the size or function of the vessel. Smallcaliber blood vessels synthesize more NO than larger ones, thus regulating the peripheral resistance, blood pressure and distribution of vascular blood flow. The basal level of NO production is higher in arteries than in veins [56]. Therefore, an indicator of normal endothelium function is its capacity for continuous synthesis of NO, required to maintain normal vascular tone. The NO synthesis is stimulated by the activation of multiple receptors located on the membrane of endothelial cells with biologically active substances: acetylcholine, kinins, serotonin, thromboxane, thrombin [43]. Being formed in the endothelium, NO diffuses into smooth muscle cells and causes dilatation of blood vessels [58]. The vasodilation is regulated by calcium and potassium ions within the vascular smooth muscle cells through the cGMP-dependent mechanism. Thus, cGMP, as a secondary mes- 
senger, mediates a range of biological effects of nitric oxide, including control of vascular tone $[83,84]$. It is very important, because in the absence of $\mathrm{NO}$ the vasodilators do not react to acetylcholine appropriately, whereas the nature of the blood vessel reaction to acetylcholine is an indicator of the vessel physiological state. Such type of reaction is called endotheliumdependent $[85,86]$.

The vascular wall containing nitric oxide synthesized in platelets and leukocytes with the help of two synthases (macrophage and endothelial), prevents adhesion and aggregation of platelets, as well as the secretion of substances, like thromboxane or serotonin, in other words, implements the atrombogene effect and does not allow an excessive vasoconstriction [87-90].

A prolonged exposure to various damaging factors (hypoxia, intoxication, inflammation, hemodynamic overload) causes a gradual depletion and distortion of compensatory dilation property of endothelium. In these circumstances, vasoconstriction is a function of smooth muscle cells [91]. Accumulation of vasoconstrictive factors in the endothelium may lead to the proliferative effect relative to the inner and middle membranes of vessels, disruption of baroreceptors structure, an increase of blood pressure, and the development of atherosclerosis $[92,93]$. The cardiovascular system is also getting disrupted, as the endothelium is damaged, its dysfunction supports the synthesis and release of vasoconstrictors, and as a result, small arteries are prone to cramps that may cause tissue hypoxia, the development of arterial hypertension and myocardial damage [92-94].

It is well-known that the inflammatory process is a basis of various pathological states [37]. The endothelium, activated under inflammatory conditions, secretes inflammatory mediators, stimulating the expression of cell adhesion molecules [95], like receptors for selectins and integrins, which are present in all immune cells. This facilitates the migration of immune cells through the endothelial barrier into the tissue, where the inflammatory process is developing [25, 37]. Each phase of the inflammatory process is associated with the appropriate NOS isoforms.

At the early stage of inflammatory reaction, under the influence of mediators (histamine, bradykinin, prostaglandins and leukotrienes) [87] a stimulation of NO production through iNOS is observed. Within the cells of vascular endothelium, NO activates soluble guanylate cyclase that leads to the intensive synthesis of cGMP, resulting in relaxation of smooth muscle cells of the vascular wall and increment of its permeability [85].

In the course of chronic inflammation, NO stimulates the release of proinflammatory cytokines - IL-1, IL-2, IL-3, IL-6, leukotrienes, chemokines, which stimulate the migration of leukocytes to the site of inflammation [61, 96-100].

Endotheliocytes lose anti-aggregatory and anti-inflammatory properties during prolonged and intensive activation, providing protrombogene vascular surface and stimulating further inflammation, which leads to the development of degenerative and necrotic changes [1]. Deficiency of endothelial NOS in the course of inflammation impairs the ability of inflammatory mediators to inhibit the expression of proinflammatory genes that prevents resolution of inflammation. Chronic inhibition of the NO synthesis (in experimental condition) provokes early manifestations of inflammatory changes within the vascular wall with varying extent 
of its damage [101, 102]. The activity of iNOS is also stimulated resulting in the excessive production and accumulation of peroxynitrite, nitrogen dioxide and hydroxyl groups, the potential targets of which are DNA and cellular proteins. High concentrations of aggressive oxygen forms activate LDL oxidation, and launch another mechanism of endothelial damage [103-105]. Under such conditions [54, 106-108] endothelium plays a key role in the pathogenesis of a number of systemic pathologies (atherosclerosis, hypertension, stroke, pulmonary hypertension, heart attack, diabetes, etc.). On the other hand, oxidative and nitro active types of stress lead not only to the cellular damage by free radicals and increased synthesis of proinflammatory mediators but also to the modification of endothelial NOreceptors [109-114].

In the course of NO metabolic biotransformation, nitric oxide is intensively synthesized, therefore, significant changes in its concentration cause the microcirculation disturbance in the area of pathological process [115]. The content of nitrite anion was found to be significantly reduced with the age. Obviously, its decrease is associated with a reduction of the cNOS activity. Instead, the iNOS activity is increased resulting in the excessive production and accumulation of peroxynitrite in tissues with age. A reduction in both oxidative (NOsynthases) and non-oxidative (arginase) ways of the arginine conversion is observed, whereas the arginase activity and urea increased with age $[78,116]$. The reason for these changes may vary from the age-related disorders in endothelial cells, reduction in the genes expression, accumulation of calcium and oxidative stress, to the lipid membranes restructuring. These disorders are considered to be a primary factor in the age-dependent pathologies of the cardiovascular system [83, 117-120].

Thus, NO, participating in the regulation of vascular tone stabilization of the permeability of the vascular wall membrane, improvement of rheological properties of the blood and suppression of proliferation of vascular smooth muscle cells and monocytes, prevents pathological reconstruction of the vascular wall. The violation of these processes is the basis for pathological changes, namely, the development of atherosclerosis, hypertension and other manifestations of endothelial dysfunction. However, a wide range of $\mathrm{NO}$ bioregulatory activity is not limited to these properties. Participating in the maintenance of all homeostatic parameters, it is directly or indirectly associated with each pathological process or extreme state of the organism. Therefore, the systems of NO synthesis and degradation, including the L-argininenitric oxide system, play an important role in the development of pathological processes within the organism. Consequently, the laboratory determination of NO metabolites or substances regulating their production is a perspective way for prognoses of many diseases.

\section{REFERENSES:}

1. Pacher P, Beckman JS, Liaudet L. Nitric oxide and peroxynitrite in health and disease. Physiol Rev. 2007;87(1):315-424.

2. Niedbala $W$, Wei XQ, Piedrafita D, Xu D, Liew FY. Effects of nitric oxide on the induction and differentiation of Th1 cells. Eur J Immunol. 1999;29(8): 2498-505.

3. Solovyov AI. Metamorphosis in "family" of nitric oxide. From the origin of life on earth to apoptosis and regulation of cellular functions and communications. Likyvannya i diagnostyka. 2003; (3):8-14. 
4. Gómez-Guerrero C, López-Franco O, Suzuki Y, Sanjuán G, Hernández-Vargas P, Blanco J, Egido J. Nitric oxide production in renal cells by immune complexes: Role of kinases and nuclear factorkappaB. Kidney Int. 2002;62(6):2022-34.

5. Sepiashvili RI. The functional immune system homeostasis. Allergology and Immunology. 2002; 4(2): 5-14.

6. Ahsan H, Ali A, Ali R. Oxygen free radicals and systemic autoimmunity. Clin Exp Immunol. 2003;131(3):398-404.

7. Hart SP, Alexander KM, Dransfield I. Immune complexes bind preferentially to Fc gamma RIIA (CD32) on apoptotic neutrophils, leading to augmented phagocytosis by macrophages and release of proinflammatory cytokines. $J$ Immunol. 2004;172(3):1882-7.

8. Babii VP. NO-dependent mechanisms of leukocyte emigration: $\mathrm{PhD}$ thesis med Sci: 14.03.04. Odessa Medical University. Odessa, 2004; 18 p.

9. McIntyre TM, Prescott SM, Weyrich AS, Zimmerman GA. Cell-cell interactions: leukocyte-endothelial interactions. Curr Opin Hematol. 2003;10(2):150-8.

10. Ignatieva $G A$. Sovremennyye predstavleniya ob immunitete. (kontury obshchey teorii). Patol Phy siol Eksp Terp. 2003; 2:2-7.

11. Sepiashvili RI, Shubich MG, Karpyuk VB. Nitric oxide in asthma and various forms of immunopathology. Astma. 2001; 2(1):5-14.

12. Adamenko GP. Cooperative interaction of poly- and mononuclear phagocytes: the effect of co-culturing cells on their chemiluminescence and secretion of myeloperoxidase. Immunologiya. 2000; 4:26-29.

13. Dushianthan A, Grocott MP, Postle AD, Cusack R. Acute respiratory distress syndrome and acute lung injury. Postgrad Med J. 2011;87(1031):612-22.

14. Yarilin AA. Symbiotic relationships of the immune system cells. Immunologia. 2001; 25(4): 16-20.

15. Zalessky VN, Phylchenkov AA Dynnik OB. Methods for visualizations of apoptosis. Journal of National Academy of Medical Sciences. 2004; 10(2): 326-38.

16. Sombra MA, Vasconcelos MP, Guimarães SB, Escalante RD, Garcia JH, Vasconcelos PR. Acute pulmonary injury induced by experimental muscle trauma. Acta Cir Bras. 2011;26 Suppl 1:43-6.
17. Sepiashvili RI, Balmasova IP. Physiological basies of operation of the new -lymphocyte subpopulations. Allerg Immunolog. 2003; 4(2): 5-14.

18. Medzhitov R. Recognition of microorganisms and activation of the immune response. Nature. 2007; 449(7164):819-26.

19. Feterowski C, Emmanuilidis $K$, Miethke T, Gerauer K, Rump M, Ulm K, Holzmann B, Weighardt $H$. Effects of functional Toll-like receptor-4 mutations on the immune response to human and experimental sepsis. Immunology. 2003;109(3):426-31.

20. Brüne $B$. Nitric oxide: NO apoptosis or turning it ON? Cell Death Differ. 2003;10(8):864-9.

21. Förstermann U, Closs EI, Pollock JS, Nakane M, Schwarz P, Gath I, Kleinert H. Nitric oxide synthase isozymes. Characterization, purification, molecular cloning, and functions. Hypertension. 1994;23(6 Pt 2): 1121-31.

22. Hickey MJ, Reinhardt PH, Ostrovsky L, Jones WM, Jutila MA, Payne D, Elliott J, Kubes P. Tumor necrosis factor-alpha induces leukocyte recruitment by different mechanisms in vivo and in vitro. $J \mathrm{Im}$ munol. 1997;158(7):3391-400.

23. de Almeida CJ, Linden R. Phagocytosis of apoptotic cells: a matter of balance. Cell Mol Life Sci. 2005;62(14):1532-46.

24. Sullivan KE, Jawad AF, Piliero LM, Kim N, Luan X, Goldman D, Petri M. Analysis of polymorphisms affecting immune complex handling in systemic lupus erythematosus. Rheumatology (Oxford). 2003;42(3):446-52.

25. Aoyagi K. Inhibition of arginine synthesis by urea: a mechanism for arginine deficiency in renal failure which leads to increased hydroxyl radical generation. Mol Cell Biochem. 2003;244(1-2):11-5.

26. Albert P, Calverley PM. Drugs (including oxygen) in severe COPD. Eur Respir J. 2008;31(5):1114-24.

27. Allen BW, Demchenko IT, Piantadosi CA. Two faces of nitric oxide: implications for cellular mechanisms of oxygen toxicity. $J$ Appl Physiol (1985). 2009;106(2):662-7.

28. Woszczek G, Chen LY, Nagineni S, Shelhamer JH. IL-10 inhibits cysteinyl leukotriene-induced activation of human monocytes and monocyte-derived dendritic cells. J Immunol. 2008;180(11):7597-603. 
29. Jyothi $M D$, Khar A. Interleukin-2-induced nitric oxide synthase and nuclear factor-kappaB activity in activated natural killer cells and the production of interferon-gamma. Scand J Immunol. 2000;52(2): 148-55.

30. Hodge S, Hodge G, Scicchitano R, Reynolds PN, Holmes M. Alveolar macrophages from subjects with chronic obstructive pulmonary disease are deficient in their ability to phagocytose apoptotic airway epithelial cells. Immunol Cell Biol. 2003; 81(4):289-96. Erratum in: Immunol Cell Biol. 2003;81(6):499.

31. Lister KJ, James WG, Hickey MJ. Immune complexes mediate rapid alterations in microvascular permeability: roles for neutrophils, complement, and platelets. Microcirculation. 2007;14(7):709-22.

32. Tejde A, Mathsson L, Ekdahl KN, Nilsson B, Rönnelid $J$. Immune complex-stimulated production of interleukin-12 in peripheral blood mononuclear cells is regulated by the complement system. Clin Exp Immunol. 2004;137(3):521-8.

33. Maianski NA, Maianski AN, Kuijpers TW, Roos D. Apoptosis of neutrophils. Acta Haematol. 2004; 111(1-2):56-66.

34. Bazilyuk OV, Kotsuruba AV, Stepanenko LG, Talanov SA, Korchak YuP, Sagach VF. Age-dependence in alteration in nitric oxide synthesis in cardiovascular system during adaptation to physical training. Int J Physiol Phatophysiol. 2010; 1(4): 345-56.

35. Blank R, Napolitano LM. Epidemiology of ARDS and ALI. Crit Care Clin. 2011;27(3):439-58.

36. Boehme MWJ, Raeth U, Scherbaum WA, Galle PR, Stremmel $W$. Interaction of endothelial cells and neutrophils in vitro: kinetics of thrombomodulin, intercellular adhesion molecule-1 (ICAM-1), Eselectin, and vascular cell adhesion molecule-1 (VCAM-1): implications for the relevance as serological disease activity markers in vasculitides. Clin Exp Immunol. 2000;119(1):250-4.

37. Manukhina EB, Downey HF, Mallet RT, Malyshev IYu. Protective and damaging effects of the periodic hypoxia: Role of nitric oxide. Vestnik Ross AMN. 2007; 2: 25-33.

38. Dergacheva TI, Shurlygina AV, Starkova EV, Verbitskaya LV, Yuklyaeva NV, Fazylov MF, Trufakin VA. Subpopulation composition of lymphocytes from regional lymph nodes, thymus and spleen in experimental inflammation of internal genitalia in female rats. Immunologiya. 2000; (5):17-9.

39. Yarilin AA. Homeostatic processes in the immune system. Control of the number of lymphocytes. Immunologiya. 2004; 25(5): 312-9.

40. Roebuck KA. Oxidant stress regulation of IL-8 and ICAM-1 gene expression: differential activation and binding of the transcription factors AP-1 and NFkappaB (Review). Int J Mol Med. 1999;4(3):223-30.

41. Dabrowska M, Grubek-Jaworska H, DomagalaKulavic J. Concentration of soluble intercellular adhesion mole-cule ICAM-1 in bronhoalveolar lavage fluid of patients with non-small cell lung cancer. Eur Respire J. 2004; 24: 82.

42. Chedraoui-Silva S, Mantovani B. The role of complement in the modulation by fluid-phase IgG of the production of reactive oxygen species by polymorphonuclear leukocytes stimulated with IgG immune complexes. Braz J Med Biol Res. 2003;36(12):1665-72.

43. Talaeva $T V$. Mechanisms of interaction of blood cells and vascular walls stand in the implementation of the inflammatory and immune responses. Ukr Rhevmatol Zh. 2001; 3-4(5-6): 45-52.

44. Dixit K, Ali R. Antigen binding characteristics of antibodies induced against nitric oxide modified plasmid DNA. Biochim Biophys Acta. 2001;1528(1): $1-8$.

45. Moser B, Loetscher P. Lymphocyte traffic control by chemokines. Nat Immunol. 2001;2(2):123-8.

46. Mayansky AN. Mitochondrias of neutrophils: physiological features and significance in apoptosis. Immunologiya. 2004; 5: 307-11.

47. Neumann P, Gertzberg N, Johnson A. TNF-alpha induces a decrease in eNOS promoter activity. Am J Physiol Lung Cell Mol Physiol. 2004;286(2):L452-9.

48. Takabayashi A, Kawai Y, Iwata S, Kanai M, Denno $R$, Kawada K, Obama K, Taki Y. Nitric oxide induces a decrease in the mitochondrial membrane potential of peripheral blood lymphocytes, especially in natural killer cells. Antioxid Redox Signal. 2000 Winter;2(4):673-80.

49. Larché $M$, Robinson $D S$, Kay AB. The role of $\mathrm{T}$ lymphocytes in the pathogenesis of asthma. $\mathrm{J} \mathrm{Al}$ lergy Clin Immunol. 2003;111(3):450-63; quiz 464. 
50. Mazepa MA, Mazepa AI. The role of apoptosis in the pathogenesis of systemic lupus erythematosus. Ukr Revmatol Zh. 2001; 3-4(5-6): 26-9.

51. Dijstelbloem HM, van de Winkel JG, Kallenberg CG. Inflammation in autoimmunity: receptors for $\mathrm{IgG}$ revisited. Trends Immunol. 2001;22(9):510-6.

52. Donn R, Alourfi Z, De Benedetti F, Meazza C, Zeggini E, Lunt M, Stevens A, Shelley E, Lamb R, Ollier WE, Thomson W, Ray D; British Paediatric Rheumatology Study Group. Mutation screening of the macrophage migration inhibitory factor gene: positive association of a functional polymorphism of macrophage migration inhibitory factor with juvenile idiopathic arthritis. Arthritis Rheum. 2002; 46(9):2402-9.

53. Alexander JJ, He C, Adler S, Holers VM, Quigg RJ. Characterization of $\mathrm{C} 3$ receptors on cultured rat glomerular endothelial cells. Kidney Int. 1997; 51(4):1124-32.

54. Semydotskaya GD, Chernyakov IA, Bezdetko TV, Khymych TY. Autoimmun syndrome during allergic diseases. Astma Allergia. 2005; 2(4): 14-7.

55. Nasonov E. Pathogenetic mechanisms of systemic vasculitis. Vrach. 2000; 5: 17-21.

56. Li H, Förstermann $U$. Nitric oxide in the pathogenesis of vascular disease. $J$ Pathol. 2000;190(3):244-54.

57. Lebedev $K A$. Immunophisiologic basics course of chronic inflammatory processes and principles of their treatment. Allerg Immunol. 2005; 6(2):161-8.

58. Bogdan C, Röllinghoff $M$, Diefenbach A. Reactive oxygen and reactive nitrogen intermediates in innate and specific immunity Immunol Rev. 2000;12(5):604.

59. Abramov AB, Komyshyn OM, Rev EY. Effect of L-arginine on the structure of lymphoid populations of the thymus. Vistnyk nauk doslidgen. 2006; 3: 84-5.

60. Biasi D, Carletto A, Caramaschi P, Bonella F, Bambara V, Pacor ML, Bambara LM. [Neutrophils in rheumatoid inflammation]. Recenti Prog Med. 2003;94(1):25-30.

61. Avdeeva $M G$, Shubych $M G$. Mechanisms pathological initiation of systemic inflammatory response syndrome. Clin lab diagnost. 2003; 3: 3-10.

62. Jancar $S$, Sánchez Crespo M. Immune complexmediated tissue injury: a multistep paradigm. Trends Immunol. 2005;26(1):48-55.
63. Hayashi M. Oxidative stress in developmental brain disorders. Neuropathology. 2009;29(1):1-8.

64. Stankevicius E, Kevelaitis E, Vainorius E, Simonsen U. [Role of nitric oxide and other endothelium-derived factors]. Medicina (Kaunas). 2003;39(4):333-41.

65. Haruta K, Kobayashi S, Tajima M, Sakai A, Tamura N, Bando H, Hara M, Kawashima S, Takasaki Y, Hashimoto $H$. Effect of immune complexes in serum from patients with rheumatoid vasculitis on the expression of cell adhesion molecules on polymorphonuclear cells. Clin Exp Rheumatol. 2001;19(1):59-68.

66. Zenkov NK, Menshchikova EB, Reutov VP. NO synthase in normal and pathological conditions of different genesis. Vestn Ros AMN. 2000; 4: 30-4.

67. Suchkov SV, Shogenov ZS, Khitrov AN, Vostrikov IL. Post-infectious autoimmune syndrome: pathogenetic features and modern protocols of clinical immunodiagnostics. Ter Arch. 2007; 4: 71-6.

68. Talaev V, Zaichenko IE, Babaykin OM, Lomunova MA. The contents of the central and effector memory cells and functional properties of T-lymphocyte in newborns and adults with different methods of activation in vitro. Immunologiya. 2005; 5: 267-74.

69. Brüne B, Sandau K, von Knethen A. Apoptotic cell death and nitric oxide: activating and antagonistic transducing pathways. Biochemistry (Mosc). 1998;63(7):817-25.

70. Bogdan C, Röllinghoff $M$, Diefenbach $A$. The role of nitric oxide in innate immunity. Immunol Rev. 2000;173:17-26.

71. Zhang C, Reiter C, Eiserich JP, Boersma B, Parks DA, Beckman JS, Barnes S, Kirk M, Baldus $S$, Darley-Usmar VM, White CR. L-arginine chlorination products inhibit endothelial nitric oxide production. J Biol Chem. 2001;276(29):27159-65.

72. Litvinenko GI. Morphocytochemical peculiarities of human blood lymphocytes in different phases of days and years cycles under normal conditions and in the development of immunodeficiency: Author. dys. kand.med.nauk. Novosibirskij medicinskiy institute. 1998; 16: 40p .

73. Malinski T. The Nitric Oxide-superoxide in dysfunctional endothelium. Abstr First Ukr. Congres Cell Biol. 2004; 207-8.

74. Nakashima T, Yokoyama A, Inata J, Ishikawa N, Haruta Y, Hattori N, Kohno N. Mucins carrying 
selectin ligands as predictive biomarkers of disseminated intravascular coagulation complication in ARDS. Chest. 2011;139(2):296-304.

75. Efremova YP, Lichkovska NE, Fafula RV, Vorobets $Z D$. NO-synthase systemin humans in the development of pathological processes. Exp Clin Physiol Biochem. 2012; 1: 68-73.

76. Tesfamariam B, DeFelice AF. Endothelial injury in the initiation and progression of vascular disorders. Vascul Pharmacol. 2007;46(4):229-37.

77. Titov $V N$. Nitric oxide in the endothelium-dependent vasodilation response. Basics unity of endothelial and smooth muscle cells in a paracrine regulation of metabolism. Clin Llab Diagn. 2007; 2:23-39.

78. Sivak $V V$. Method of free circulating endothelial cells in the blood determination. Patent N 2007 02080 (Ukraine) 25,012 U IPC G01N33/55. Bulleten. N11: 2.

79. Dignat-George F, Sampol J. Circulating endothelial cells in vascular disorders: new insights into an old concept. Eur J Haematol. 2000;65(4):215-20.

80. Bozza FA, Gomes RN, Japiassú AM, Soares M, Castro-Faria-Neto HC, Bozza PT, Bozza MT. Macrophage migration inhibitory factor levels correlate with fatal outcome in sepsis. Shock. 2004;22(4):309-13.

81. Plotnikoff NP, Faith RE, Murgo AG, Good RA. Cytokines: Stress and Immunity. Boca Raton: CRC Press, 2006: 2nd Edition: 405 p.

82. Maksimenko AV, Turashev AD. Endothelial glycocalyx of the circulatory system: Detection, the components, structural organization. Russ J Bioorganic Chem. 2014; 40(2): 119-28.

83. $W u C V$. Nitric oxide and inflammation. Curr Med Chem Anti Inflamm Anti Allergy Agents. 2004; 3(3):217-22.

84. Ke X, Terashima M, Nariai Y, Nakashima Y, Nabika T, Tanigawa $Y$. Nitric oxide regulates actin reorganization through cGMP and $\mathrm{Ca}(2+)$ /calmodulin in RAW 264.7 cells. Biochim Biophys Acta. 2001;1539(1-2):101-13.

85. Lupinskaya ZA, Zarifyan AG, Gurovich TC, Schleifer $S G$. The endothelium: function and dysfunction B.: KRSU, 2008; 373 p.

86. Bachschmid M, Thurau S, Zou MH, Ullrich V. Endothelial cell activation by endotoxin involves su-
peroxide/NO-mediated nitration of prostacyclin synthase and thromboxane receptor stimulation. FASEB J. 2003;17(8):914-6.

87. Bucci M, Roviezzo F, Posadas I, Yu J, Parente L, Sessa WC, Ignarro LJ, Cirino G. Endothelial nitric oxide synthase activation is critical for vascular leakage during acute inflammation in vivo. Proc Natl Acad Sci U S A. 2005;102(3):904-8.

88. Gao L, Flores C, Fan-Ma S, Miller EJ, Moitra J, Moreno L, Wadgaonkar R, Simon B, Brower R, Sevransky J, Tuder RM, Maloney JP, Moss M, Shanholtz C, Yates CR, Meduri GU, Ye SQ, Barnes KC, Garcia JGN. Macrophage migration inhibitory factor in acute lung injury: expression, biomarker, and associations. Translational Research. 2007; 150(1): 18-29.

89. Bethel K, Luttgen MS, Damani S, Kolatkar A, Lamy R, Sabouri-Ghomi M, Topol S, Topol EJ, Kuhn P. Fluid phase biopsy for detection and characterization of circulating endothelial cells in myocardial infarction. Phys Biol. 2014;11(1):016002.

90. Kravchenko NA, Yarmash NV. Biochemical and molecular genetic mechanisms of synthesis of nitric oxide in endothelial NO-synthase in norm and cardiovascular diseases. Ukr Therapeut Zh. 2007; 1: 82-3.

91. Russo S, Bussolati B, Deambrosis I, Mariano F, Camussi $G$. Platelet-activating factor mediates CD40-dependent angiogenesis and endothelialsmooth muscle cell interaction. J Immunol. 2003;171(10):5489-97.

92. Boos CJ, Soor SK, Kang D, Lip GY. Relationship between circulating endothelial cells and the predicted risk of cardiovascular events in acute coronary syndromes. Eur Heart J. 2007;28(9):1092-101.

93. O'Donnell VB, Freeman BA. Interactions between nitric oxide and lipid oxidation pathways: implications for vascular disease. Circ Res. 2001;88(1):12-21.

94. Damani S, Bacconi A, Libiger O, Chourasia AH, Serry R, Gollapudi R, Goldberg R, Rapeport K, Haaser S, Topol S, Knowlton S, Bethel K, Kuhn P, Wood M, Carragher B, Schork NJ, Jiang J, Rao C, Connelly M, Fowler VM, Topol EJ. Characterization of circulating endothelial cells in acute myocardial infarction. Sci Transl Med. 2012;4(126):126ra33.

95. Kitamoto S, Egashira K, Kataoka C, Koyanagi M, Katoh M, Shimokawa H, Morishita R, Kaneda Y, 
Sueishi K, Takeshita A. Increased activity of nuclear factor-kappaB participates in cardiovascular remodeling induced by chronic inhibition of nitric oxide synthesis in rats. Circulation. 2000;102(7):806-12.

96. Ivanov AN, Norkyn IA, Puchynyan DM, Shirokov VJ, Zhdanova OJ. Adhesive endothelial moleculesofvascular-wall. Usp Fiziol Nauk. 2014; 45(4): 34-49.

97. Gallagher PM, Lowe G, Fitzgerald T, Bella A, Greene CM, McElvaney NG, O'Neill SJ. Association of IL-10 polymorphism with severity of illness in community acquired pneumonia. Thorax. 2003; 58(2):154-6.

98. Festa A, D'Agostino R Jr, Williams K, Karter AJ, Mayer-Davis EJ, Tracy RP, Haffner SM. The relation of body fat mass and distribution to markers of chronic inflammation. Int $J$ Obes Relat Metab Disord. 2001;25(10):1407-15.

99. Rönnelid J, Tejde A, Mathsson L, Nilsson-Ekdahl K, Nilsson $B$. Immune complexes from SLE sera induce IL10 production from normal peripheral blood mononuclear cells by an FcgammaRII dependent mechanism: implications for a possible vicious cycle maintaining B cell hyperactivity in SLE. Ann Rheum Dis. 2003;62(1):37-42.

100. DiMeo D, Tian J, Zhang J, Narushima S, Berg DJ. Increased interleukin-10 production and Th2 skewing in the absence of 5-lipoxygenase. Immunology. 2008;123(2):250-62.

101. Schmidt P, Youhnovski N, Daiber A, Balan A, Arsic M, Bachschmid M, Przybylski M, Ullrich V. Specific nitration at tyrosine 430 revealed by high resolution mass spectrometry as basis for redox regulation of bovine prostacyclin synthase. $J$ Biol Chem. 2003;278(15):12813-9.

102. Fantuzzi G. Adipose tissue, adipokines, and inflammation. J Allergy Clin Immunol. 2005;115(5):911-9.

103. Bloodsworth A, O'Donnell VB, Freeman BA. Nitric oxide regulation of free radical- and enzyme-mediated lipid and lipoprotein oxidation. Arterioscler Thromb Vasc Biol. 2000;20(7):1707-15.

104. Forstermann $U$. Endotelial NO synthase as a source of NO and superoxide. Eur J Clin Pharmacol. 2006; 62(1): 5-12.

105. Nagy G, Koncz A, Telarico T, Fernandez D, Ersek B, Buzás E, Perl A. Central role of nitric oxide in the pathogenesis of rheumatoid arthritis and systemic lupus erythematosus. Arthritis Res Ther. 2010;12(3):210.

106. Norman MU, Lister KJ, Yang YH, Issekutz A, Hickey $M J$. TNF regulates leukocyte-endothelial cell interactions and microvascular dysfunction during immune complex-mediated inflammation. $\mathrm{Br} J$ Pharmacol. 2005;144(2):265-74.

107. Kaur C, Ling EA. Antioxidants and neuroprotection in the adult and developing central nervous system. Curr Med Chem. 2008;15(29):3068-80.

108. Kalinichenko OV, Myshunina TN, Dronko MD. The activity of nitric oxide synthase concentration in tissue of persons with thyroid carcinomas. Fiziol Zh. 2016; 62(3): 9-19

109. Moncada $S$. Nitric oxide and cell respiration: physiology and pathology. Verh K Acad Geneeskd Belg. 2000;62(3):171-9.

110. Strutynska NA, Kotsyuruba AV, Bud'ko AJ, Mys LA, Sagach VF. Dysfunction of mitochondria in the heart of aging whith accompanied withtensionsof constitutive NO-synthase on the background of oxidative and nitrosoactive stress. Fiziol Zh. 2016; 62(2): 3-11

111. Diefenbach A, Schindler H, Donhauser N, Lorenz E, Laskay T, MacMicking $J$, Röllinghoff $M$, Gresser I, Bogdan C. Type 1 interferon (IFNalpha/ beta) and type 2 nitric oxide synthase regulate the innate immune response to a protozoan parasite. Immunity. 1998;8(1):77-87.

112. Shapoval LN. Contribution of nitric oxide and mitochondrial permeability transition to the cardiovascular control in hypertension and experimental hyperglycemia. Advances in biomedical research, University of Cambridge, UK, February 23-25. 2010; 127-132.

113. Poon BV, Raharjo E, Patel KD, Tavener S, Kubes $P$. Complexety of inducible nitric oxide synthase. Circul ation. 2003; 108: 1107-15.

114. Price S, Mitchell JA, Anning PB, Evans TW. Type II nitric oxide synthase activity is cardio-protective in experimental sepsis. Eur J Pharmacol. 2003; 472(12):111-8.

115. Lubrano V, Vassalle C, Blandizzi C, Del Tacca $M$, Palombo C, L'Abbate A, Baldi $S$, Natali A. The effect of lipoproteins on endothelial nitric oxide synthase is modulated by lipoperoxides. Eur J Clin Invest. 2003;33(2):117-25. 
116. Kawana $S$. Vascular endothelial cell injury in allergie vasculitis. Journal of the Nippon Medical School. 1998; 65(3): 1950-2000.

117. Goshovska Yu, Korkach Yu, Shimanskaya T, Kotsuruba A, Sahach V. Effect of genipin at NO synthesis and ischemia-reperfusia induced oxidative stress in old rat heart. Int $J$ Physiol Pathophysiol. 2010; 1(4): 335-44.

118. Carvour M, Song C, Kaul S, Anantharam V, Kanthasamy A, Kanthasamy A. Chronic low-dose oxidative stress induces caspase-3-dependent PKCdelta proteolytic activation and apoptosis in a cell culture model of dopaminergic neurodegeneration. Ann N Y Acad Sci. 2008;1139:197-205.

119. Wever RM, Lüscher TF, Cosentino F, Rabelink TJ. Atherosclerosis and the two faces of endothelial nitric oxide synthase. Circulation. 1998;97(1): 108-12.

120. Li H, Oehrlein SA, Wallerath T, Ihrig-Biedert I, Wohlfart P, Ulshöfer T, Jessen T, Herget T, Förstermann $U$, Kleinert $H$. Activation of protein kinase $\mathrm{C}$ alpha and/or epsilon enhances transcription of the human endothelial nitric oxide synthase gene. Mol Pharmacol. 1998;53(4):630-7.

\section{Оксид азоту як основний поліфункціональний регулятор імунокомпетентних та ендотеліальних клітин}

О. В. Садляк, М. Л. Байда, М. А. Колішецька, Х. Г. Мусій-Семенців, Н. Г. Семенців, Р. Б. Лесик

Оксид азоту (NO) відіграє важливу роль в метаболізмі. Отже, кожна тканина нашого тіла піддається ушкодженню при зміні концентраціі оксиду азоту і його метаболітів. У статті проаналізовано фенотиповий ефект оксиду азоту та його метаболітів у макрофагах, NK- клітинах, лімфоцитах, який забезпечує захист організму від злоякісних новоутворів та внутрішньоклітинних збудників. Дисбаланс в імунній відповіді може бути спричинений дисрегуляцією синтезу NO.
Оксид азоту також відіграє важливу роль в розвитку ендотеліальноі дисфункціi, яка полягає в інгібуванні адгезіi та агрегаціі тробмоцитів, порушенні регуляціі вазоконстрикціі та вазодилатаціі, змінах реологічних властивостей крові та формуванні атеросклеротичних бляшок. Отже, дисбаланс в синтезі оксиду азоту ендотелієм судин може бути раннім маркером розвитку різноманітних патологій .

К л ю ч о в і с л о в а: NO-синтази, лімфоцити, імунна систкма, запалення, ендотеліальна дисфункція, ендотеліоцити.

\section{Оксид азота как основной полифункцио- нальный регулятор иммунокомпетентных и эндотелиальных клеток}

О. В. Садляк, М. Л. Байда, М. А. Колишецкая, Х. Г. Мусий-Семенцив, Н. Г. Семенцив, Р. Б. Лесык

Оксид азота (NO) играет важную роль в метаболизме. Поетому, каждая ткань нашего тела поддается повреждению при смене концентрации оксида и его метаболитов. В статье ми анализируем фенотипический ефект оксида азота и его метаболитов в макрофагах NKклетках, лимфоцитах, которий обеспечивает защиту организма от злокачественных новообразований и внутриклеточных возбудителей. Дисбаланс в иммунном ответе может бить обусловлен дисрегуляцией синтеза NO. Оксид азота играет важную роль в разитии ендотелиальной дисфункции, суть которой в ингибировании адгезии и агрегации тромбоцитов, нарушении регуляции вазоконстрикции и вазодилатации, изменении реологических свойств крови и формировании атеросклеротических бляшек.Поэтому дисбаланс в синтезе оксида азота ендотелием сосудов может бить ранним маркером развития разнообразных патологий.

К л юч е в ы е с с о в а: NO-синтазы, лимфоциты, иммунная система, воспаление, эндотелиальная дисфункция, эндотелиоциты.

Received 16.06.2017 